\title{
Arctic region and arctic cities VS sustainable region and smart cities
}

\author{
Gennadij Detter ${ }^{1, *}$, Josif Tukkel ${ }^{2}$, and Anastasia Ljovkina ${ }^{1}$ \\ ${ }^{1}$ Socio-Economic Research Sector, Arctic Scientific Research Center, 629007, Salekhard, Russia \\ ${ }^{2}$ Graduate School of Cyber-Physical Systems and Control, Peter the Great St. Petersburg Polytechnic \\ University, 195251, Saint Petersburg, Russia
}

\begin{abstract}
Existing crises of arctic sustainable development and continuous increase of the VUKA world tendencies require urgent reconsidering economic and political models in the Arctic region, considering modern global trends, technological, political, socio-cultural conditions, and Russian national development goals. One of the key global trends is rapid urbanization and "smart cities" as a solution to the increasing problems of urban sustainable development. The level of urbanization in the Arctic zone of the Russian Federation exceeds the average for the whole world. In this research, we focus on the problem of arctic sustainable "smart cities". We analyzed existing approaches and concepts of "Smart City" and classified them into three main groups: system (complex) approach, technological approach, and socio-cultural approach. We showed different basic axiomatics and priorities in these approaches, which logically result in different social consequences. We suggested the socio-cultural approach as most relevant to the humanistic sense of developing smart cities and purposes of sustainable development. In particular, implying this approach in developing Arctic smart cities will allow using Arctic advantages and wealth for long-perspective human development and increasing the quality of life of Arctic people.
\end{abstract}

\section{Introduction}

After the destruction of the Soviet economy, the economic and political frameworks of the Arctic regions froze in the conditional balance between the market-oligarchic system of distribution of added value arising from the rent of natural resources and the statepaternalistic system of regional management, providing relatively high standards of consumption and social security of the arctic population. This situation in combination with Arctic rich deposits favored the false impression that the economic prosperity of the arctic territories will be long-lasting. However, a series of social-economic crises showed that there are significant flaws in the actual model of the Arctic development, which do not guarantee its sustainable development.

The twenties of the XXI century began with significant global financial, economic, and social crises, revealing deep crises of sustainable development at different levels: global,

*Corresponding author: detter@mail.ru 
national, and regional [1-3]. The crises, forced with additional adverse events, such as a pandemic, revealed hidden social-economic problems (conflicts and imbalances) and the overall system imperfection of existing models of behavior and achievement of goals. These conditions opened the opportunities for the transition to sustainable innovative development on the new level of social evolution, and require a transformation of outdated socialeconomic models, including replacing ineffective or outdated communication and interaction forms, institutes, and standards [4].

The Arctic is a vast and richest macro-region, uniting seven countries, with huge reserves of natural resources (294 deposits of oil and gas, 350 deposits of gold) which stipulate an important role of the Arctic in geopolitical and geoeconomic scenario increasing with the unprecedented climate warming over the past centuries [5]. One of the key advantages of the Arctic contribution to unlocking its social-economic potential is the Northern Sea Route, which connects more than 10 ports in Russia, as well as the Barents-Euro-Arctic with the Asia-Pacific transport corridors, allowing to decrease twice the distance between the ports of Murmansk and Yokohama (Japan).

Nevertheless, negative consequences of maintaining the traditional economic model and political framework are increased in the Arctic regions and cities, considering Arctic ecological vulnerability [6] and the world transition to a green economy [7]. This risk can be overcome through maintaining self-sufficiency, independence, and sustainability through innovative Arctic development, aiming at improving the quality of life and the long-term viability of arctic territories [8]. At the same time, the low level of science intensity in arctic economic activities, social life, and management is the reason for the slow transformation of traditional social-economic models of arctic development and their conflict with modern social relations and external structures of the world economy, which have superior development dynamics. Existing crises of arctic sustainable development and continuous increase of the VUKA world tendencies require urgent reconsidering economic and political models in the Arctic region, considering global modern trends, technological, political, sociocultural conditions, and Russian national development goals [9].

\section{Research focus and methodology}

Rapid urbanization is a global trend, which is accompanied by an increase in problems related to energy, resource supply, urban ecology, human development, the resolution of which requires new management models [10]. Arctic cities are determined by the fact of being on the land territory of the Russian Arctic [11]. The level of urbanization in the Arctic zone of the Russian Federation (AZRF) exceeds the average for the whole world. Thus, the lowest level of urbanization in 2018 was in the Republic of Sakha Yakutia - 66.1\%, the highest was in the Murmansk region - 92.2\% [12], while the average urbanization in Russia in 2018 was $74.7 \%$, and in the world $-54 \%$ [13].

AZRF has a low population density -0.641 people $/ \mathrm{km} 2$, including 2.898 people $/ \mathrm{km} 2$ on the European part and 0.264 people $/ \mathrm{km} 2$ on the Asian part. The population is mainly concentrated in cities, the population density of which reaches 1793 people $/ \mathrm{km} 2$ (Murmansk). The area of the most developed territories occupies $2 \%$ of AZRF and includes $80 \%$ of its population [14]. Thus, the economy of the Russian Arctic is concentrated, in small areas of the most economically developed cities. Almost a quarter (24.3\%) of the AZRF economy is concentrated in the Purovsky region of the Yamal-Nenets Autonomous Okrug. Taking into account the poor transport infrastructure and narrow specializations of the Arctic regions, the economy of the Russian Arctic can be presented as the sum of the economies of cities, settlements, and shift camps, not interconnected by goods and markets. Arctic cities have specific local economies with a population employed mostly in the local extractive industrial activities, including management, budgetary sphere, and service businesses. The 
trends post-industrial society influence Arctic cities - the role of industry in urban life and employment of the population sufficiently decreased in many Arctic cities, for example, in Naryan-Mar, Salekhard, Anadyr, which are increasingly become specialized in the services, education, health care, management rather than industrial production.

Thus, arctic sustainable development depends on arctic cities sustainable development to a great extent and requires reconsidering their development models, considering global trends, modern technological, political, and socio-cultural conditions.

The purpose of the study is to find approaches and concepts of "Smart City", which most relevantly will allow using Arctic advantages and wealth for long-perspective sustainable development and increasing quality of life of Arctic people.

In our research, a concept of "smart city" is viewed through a system approach - as a set of interrelated elements, where the properties of the whole system are determined not only by the properties of individual elements but also by the interrelationships that they form. We based on activity theory giving a priority of a person (subject) in development activities (selfdevelopment and development of the living environment), designed for sustainable development of the community and improving the quality of life (humanistic approach, the concept of sustainable development). In our research, we used existing statistical reviews and empirical research, theoretical analysis, and synthesis.

\section{Results}

The world level of technological development makes it possible to implement a modern model of city management based on digital technologies - "smart city". This concept began developing in the 1990s when information and communication technologies became widely available. Tech giants such as IBM, Siemens, Cisco Systems have come up with their smart city concepts that can be used by municipal governments to achieve "unprecedented" levels of efficiency, safety, convenience, and resilience. This approach represents the digitization of urban space in the interests of large agents of influence - large multinational corporations, regional and municipal authorities that develop urban communications, infrastructure control networks, and city security.

The genesis of "smart cities" is based on the development of high technologies and the corresponding adaptive socio-cultural changes. The convergence of high technologies, economics, law, and social psychology allows the creation of new types of formations "smart cities" that unite communities of people through industrial platform solutions [15]. Industrial platforms create the hardware and software needed to move traditional manufacturing to the Internet, thereby lowering production costs [16]. By dramatically accelerating the exchange of information and goods, "smart cities" contribute to the cultural evolution of society.

Smart city projects are based on such basic concepts as the quality of life, digital transformation of infrastructure management and communications, and resource-saving economy. However, often the concept of a "smart city" is reduced only to the city management digitalization providing an extremely narrow interpretation of the "smart city" concept. This reduction leads to the low efficiency of investments in innovation due to the lack of a strategic vision of the main sense of digital transformations. The accentuation on the technological side of "smart city" leaves the city without any meaningful evolution of the socio-cultural context, lead to the expansion of digitalization of existing processes, digitalization of consumption, but not to a qualitatively new sustainable socio-cultural development of cities.

The criticism of this "technological approach" began in 2013. Adam Greenfield, examining the processes of the "smart city" in his book "Against the smart city" noted that in the frames of "technological approach", a digital city will not and cannot serve the interests 
of the people who live in it [17]. Anthony Townsend also problematized the "neutrality" of smart city technologies [18]: they make life more comfortable but people pay for this with a part of their "freedom". The solution to this problem can be found in a democratic initiative from below in the cooperation of citizens, corporations, and municipalities. The smart city mechanism should be primarily initiated by people as its main sense is to provide people viability [18].

Besides, wealth and consumption being main indicators of the quality of life in the 20th century were questioned by A. Sen, who rethought the concept of quality of life from the standpoint of human development [19]. The idea of human development as expanding people's choices by expanding human abilities and capabilities formed the basis of the Human Development Report (HDR), which has been issued under the auspices of UNDP since 1990. Today Human Development Index (HDI) is the most widely recognized tool for monitoring the quality of life.

In a broad sense, a "smart city" concept presupposes preferential investment in the development of human and social potential, aiming at sustainable socio-economic development, rational, most efficient management of natural resources, high quality of life, and participation of all members of the urban community in the development of the city as a place of life [20]. This concept implies rational joint management of natural resources, significant involvement of the entire population in the development of the cultural space, synergistic interaction of all stakeholders (local community, business, municipal authorities) in the development of socio-cultural urban context. Horizontal interactions, network nonhierarchical social structures are an alternative to the control of large companies, decisions, and projects from the "top" [21].

It would be logically erroneous to say that the presence of "smart" infrastructure, an increase in the level of "digital consumption" and the number of digitalized processes in itself should lead to the solution of many urban problems, provide sustainable development, and improve the quality of life (human development). Digitalization of the city's life is neither a value nor a since in itself nor a panacea for solving the problems of sustainable development of the city. Digitalization, digital transformation is just a modern trend and a tool for innovative development [22], which acts efficiently and humanely if it serves clear defined short-term and long-term socio-cultural goals.

With the "narrow" approach, the real needs of the population and many negative socioeconomic consequences of digitalization are not taken into account, which is why the strategic goals of increasing the sustainability of the city's development cannot be achieved. The implementation of a broad approach to the "smart city" implies, first of all, defining the meanings of the city's development and, accordingly, the mission of its digital transformation, which makes it possible to synergistically and meaningfully design technological and digital solutions for the "smart city". This approach requires specific management competencies: the ability to integrate management decisions taken at various levels, systemic thinking, interdisciplinary thinking, networking, etc. [23].

The implementation of a "smart city" in the broadest sense of this concept is demonstrated by. The development of the majority of modern European and North American "smart cities" is based on an integrated, "broad" approach [24]. The concept of "smart city" is implemented "from the bottom up" in several stages, based on the interests of numerous stakeholders. The emphasis is on the development of human potential, building a multidimensional interaction aimed at sustainable development through a qualitative transformation of the urban environment and society itself. The city is viewed as a "system of systems", where the interaction of individual subsystems, technological and social innovations serve the harmonious co-development development of different groups and overall city's sustainable development [23].

According to the concept of "smart city", developed by the Ministry of Construction, 
Housing and Utilities of the Russian Federation, a smart city is a city that implements and uses a set of advanced digital and engineering solutions and organizational measures aimed at achieving the highest possible efficiency in resource management and service delivery, creating stable favorable living and business conditions for current and future generations [25]. This definition corresponds to the views of Russian researchers [26]. It presupposes "the purposeful implementation of the concept of creating a digital economy, the active introduction of advanced information and telecommunication technologies, the creation of smart cities and networks for sustainable development, ensuring high living standards of the population and conditions for the harmonious development of the individual based on the transition to a highly efficient economy" [27]. It also corresponds European concept of «smart city» [28] and international experience of creating smart cities [29].

Nevertheless, theoretical analysis of the concept of development of the Russian "smart cities" allows us to conclude that they still rely mainly on a narrow, "technological" or "digital" approach, assuming "technologies for people, and people for technologies", making "people happy" through the digital transformation of processes and implementation of technological innovations. But this approach has sufficient strategic constraints for real sustainable development. A.G. Teslinov notes that the analysis of the Program of the Digital Economy of Russia and the public rhetoric that follows it reveals incorrect basic attitudes and beliefs that people develop when they are given advanced tools of activity, and that the system of economic relations is developing by digital trends [30]. Thus, the current traditional and official concept of "smart cities" corresponds technological approach but not completely adequate to socio-cultural, humanistic approaches and activity theory, which are the most valid methodological basis for the solving the problems of social development [31-35].

Table 1. Characteristics of the main approaches to the development of smart cities.

\begin{tabular}{|c|c|c|c|}
\hline Approach & $\begin{array}{l}\text { The specificity of the } \\
\text { approach }\end{array}$ & $\begin{array}{l}\text { Specificity of } \\
\text { management }\end{array}$ & $\begin{array}{l}\text { Example of authors } \\
\text { developing the } \\
\text { approach }\end{array}$ \\
\hline $\begin{array}{l}\text { Systems } \\
\text { approach } \\
\text { (Integrative } \\
\text { approach) }\end{array}$ & $\begin{array}{l}\text { Emphasis on the convergence } \\
\text { of high technology, } \\
\text { economics, law, and social } \\
\text { psychology. Assumes the } \\
\text { mutual influence of } \\
\text { technological development } \\
\text { and socio-cultural } \\
\text { innovations. The main goal is } \\
\text { synergistic systemic effects } \\
\text { for all spheres of life and all } \\
\text { stakeholders. }\end{array}$ & $\begin{array}{l}\text { Participatory } \\
\text { management. } \\
\text { A developed system of } \\
\text { communications and } \\
\text { multidimensional } \\
\text { interactions between } \\
\text { stakeholders aimed at a } \\
\text { qualitative } \\
\text { transformation of the } \\
\text { urban environment and } \\
\text { the society. }\end{array}$ & $\begin{array}{l}\text { Altukhov A.V., } \\
\text { Dorofeeva A.A., } \\
\text { Ganin O.B., } \\
\text { Ganin I.O., } \\
\text { Mizraki M.V. }\end{array}$ \\
\hline $\begin{array}{l}\text { Technological } \\
\text { approach } \\
\text { (Process } \\
\text { approach) }\end{array}$ & $\begin{array}{l}\text { Emphasis on translating } \\
\text { traditional production onto } \\
\text { the Internet. Assumes the } \\
\text { leading role of technology } \\
\text { development and the } \\
\text { corresponding adaptation of } \\
\text { society. The main goal is to } \\
\text { reduce production costs, } \\
\text { increase the controllability of } \\
\text { the processes of urban life. }\end{array}$ & $\begin{array}{l}\text { The traditional system } \\
\text { of power and decision- } \\
\text { making with } \\
\text { predominant } \\
\text { consideration of the } \\
\text { interests } \\
\text { corporations. } \\
\text { Development of the } \\
\text { corporate university } \\
\text { system, research, and } \\
\text { development. } \\
\text { Emphasis on the } \\
\text { development } \\
\text { adaptation mechanisms } \\
\text { for the better inclusion }\end{array}$ & $\begin{array}{l}\text { Srnichek N., } \\
\text { Kurcheeva G.I., } \\
\text { Klochkov G.A. }\end{array}$ \\
\hline
\end{tabular}




\begin{tabular}{|c|c|c|c|}
\hline & & $\begin{array}{l}\text { of citizens in the digital } \\
\text { transformation of the } \\
\text { city. }\end{array}$ & \\
\hline $\begin{array}{l}\text { Sociocultural } \\
\text { approach }\end{array}$ & $\begin{array}{l}\text { Emphasis on digital } \\
\text { neutrality. Problematization } \\
\text { of socio-cultural problems } \\
\text { and consequences of the } \\
\text { introduction of smart city } \\
\text { technologies. Prioritization of } \\
\text { the humanistic meanings and } \\
\text { goals of the smart city, which } \\
\text { serve as guidelines for the } \\
\text { development of technology. }\end{array}$ & $\begin{array}{l}\text { The high responsible } \\
\text { activity of city citizens, } \\
\text { determining the } \\
\text { direction of technology } \\
\text { development. } \\
\text { Reflexive management, } \\
\text { reflexive innovation } \\
\text { environment. } \\
\text { Developed } \\
\text { technologies of self- } \\
\text { government and } \\
\text { network interactions } \\
\text { aimed at human } \\
\text { development and } \\
\text { increasing the vitality } \\
\text { of the community. }\end{array}$ & $\begin{array}{l}\text { Greenfield A., } \\
\text { Anthony M., } \\
\text { Townsend E., } \\
\text { Sen A. }\end{array}$ \\
\hline
\end{tabular}

This research substantiated the strategic value of "smart city" research considering the cities' proactive development by their inhabitants, which must be considered in the design of conceptual, strategic socio-humanitarian studies. Characteristics of a synergistic selfdeveloping socio-cultural "smart city" system were formulated: continuous innovations that improve the quality of life of people, social heterogeneity, consensuality, the predominance of the intellectual nature of spiritual life; strategic use of information and communication infrastructure, planning and management that meets the social and economic needs of society, rational and effective participative management of natural resources, common priorities for sustainable development, a multi-party strategy of a sustainable "smart city", etc. In this approach, a person and his living environment are in constant interaction, in which a person is an active subject of the co-related transformation of the living environment and selfdevelopment. The basic ontological aim of such interaction is to increase the viability of the entire urban community as a system, and in general - the viability of the whole society as a system of interconnected viable "smart cities".

A "smart city" in this context is a platform for generating new knowledge and a sociocultural environment for human development. The development of "smart cities" is based on interrelated processes of scientific and technological development and the development of the human potential of urban communities. The convergence of high technologies, economics, law, and social psychology allows the creation of new types of formations that unite communities of people through industrial platform solutions [36]. In other words, the socio-economic development of the city and the improvement of the quality of life will become possible only to the extent that the people themselves become smarter, kinder, stronger, more responsible, active, and innovative.

\section{Discussion}

The city is a complex spatial socio-cultural system, the result of historical, cultural, and economic processes, providing a set of life conditions and opportunities for its population. The city accumulates human potential, «increases its mass and density", promoting various cultural processes that would not happen in small communities. The city provides an opportunity to transform human potential into activity and capitalize it to the social-cultural changes, technologies, innovations, and knowledge. People, "spiritual monads", form the cultural space of cities, which, in its turn, forms the basis of people's self-awareness and 
identity.

A specific feature of the Arctic cities since the period of market reforms is the increased mobility of the population, which washes away a sufficient part of the historical heritage, social-cultural capital, technological competencies, skills, meanings, and attitudes. Population changeability brings new knowledge and culture, however, existing studies do not answer the question, how these novelties influence the cultural level of the Arctic communities and cities. Particularly short periods of population stay and turnover (shift regime) stipulates sociocultural space degrading as it works primarily to meet the most basic needs of the population, thus the city community loses its memory, does not make plans for the future, and has poor chances for sustainable development. The material environment in such Arctic cities (architecture in particular) does not carry the function of information and cultural codes storage due to the poor materials used and the temporality of its purpose, with rare exceptions.

The Arctic city is a special category of settlements in Russia that differ from the northern city. The Arctic city is characterized by harsher climatic conditions, remoteness, life on the edge, on the frontier. For example, St. Petersburg is a northern city, but not an Arctic city. The solutions suitable for a northern city are not always acceptable for arctic cities. The energy supply problems in the Arctic cities are much more urgent than in the southern and northern cities of the country. Remoteness from large industrial centers and agricultural areas increases the costs and the requirements for transport infrastructure. Shifting the paradigm of the planned development of the Arctic oil and gas economy led to the replacement of a permanent labor force with a temporary one, decreasing in the social responsibility of large business to the regions and the population, and uncertain long-term prospects and scenarios for the development of Arctic cities and settlements, including their compression and closure. The growth of problems associated with the development of human potential and sustainable development of arctic territories deepens scientific and technological lag in Arctic cities, enhances emigration processes (educational, retirement), depopulation, and other negative social-demographic processes. The common problems of the Arctic settlement, negatively influencing its socio-cultural space by reducing it to serving basic needs, are the absence of higher educational institutions, underdeveloped research activities, poor cultural and art institutions, lack of centers of technological development. Arctic agriculture is underdeveloped as well, and a high level of food security risks remains. At the same time, Arctic cities also contain the typical features of an ordinary city.

An Arctic city can be presented as a set of social, economic, and cultural spaces and processes with specific characteristics (climate, remoteness, infrastructure), the active elements of which are social agents, communities, and institutions capable of ensuring their sustainable functioning and environmental safety. The typology of Arctic cities implies their generic characteristics and differences. Arctic cities remain unattractive for living due to extreme climatic conditions, isolation from the "Big Earth", a large gap in the quality of life. They require much greater efforts in addressing the issue of increasing the attractiveness of living, ensuring sustainable development, and a high level of quality of life compared to the central and southern regions. Nevertheless, there is no clear sociocultural concept of arctic "smart cities" that ensures their attractiveness, sustainable development together with the achievement of common national goals in the Arctic.

Increasing demands of the people for the quality of life, on the one hand, and increasing economic, technological, climatic, and environmental challenges, on the other hand, pose new tasks to the authorities of arctic cities and regions. These tasks are related to improving the reliability of infrastructure, reducing the risks of environmental pollution, ensuring safety against man-made and climatic disasters, new businesses and jobs creation, access to quality education, health care, and housing. The most urgent problem is decreased level of technological development in Arctic cities which resulted in the growth of unemployment, 
decrease in per capita income, and decline in the safety of the population in extremely severe natural and climatic conditions. At the same time, these challenges reveal new opportunities for economic growth, innovations, and social transformation.

The human factor is one of the reasons why Arctic cities lose in the competition for a high standard of living. Arctic cities require specific human potential to overcome challenges in comparison with northern and southern cities, but the intellectual, educational level of Arctic cities is one of their weakest points. The citizens of arctic cities need the development of specific competencies for ensuring arctic sustainable development, which implies large opportunities to gain knowledge, special state educational programs, and support policy. In addition, it is important to ensure a balance between the outflow of talented people (including educational migration) and the inflow of highly qualified specialists coming to the Arctic (including return after-education migration).

The need for human development to ensure sustainable development of Arctic cities invariably determines the use of a broad approach to the concept of a "smart city", the development of its socio-cultural concept, which allows to design and organize innovation and processes of digital and technological transformation meaningfully and synergistically. The development and implementation of new socio-cultural arctic cities' concepts will allow to increase the level of human potential, increase the efficiency of city management, and use available human and technological resources effectively. If Arctic cities fail to meet the growing challenges and demands for the quality of life, their potential for long-term viability will sufficiently decrease. Systemic measures and reforms of city management models aimed at increasing quality of life and cities' sustainable development are needed to prevent the threat of depletion of human potential and reducing the space of the arctic city to the survival regime.

Simple digitalization of processes and replication of technological solutions are especially dangerous for Arctic cities. There is a lack of local competencies and knowledge in the implementation of digital technologies and, therefore, a risk of decreasing the employment of the endemic population together with increasing the number of temporary immigrants (digital professionals and specialists). At the same time, smart use of digital technologies focused on the needs of the population can make a sufficient input in solving traditional arctic problems, for example, can reduce the emigration of talented youth. Our previous study revealed the readiness of $90 \%$ of young people to change their intention for educational migration in the case of targeted use of digital transformation for increasing the quality of education in the arctic and solving other youth problems.

Thus, developing a "smart" model of managing an Arctic city requires involving a wide range of actors in a discussion of development values and priorities. The sociocultural space should be advantageous to people with different constructive goals and interests and with different income levels, so that everyone can realize their own needs and creative potential, without entering into conflict with others. Socio-cultural, humanistic, and activity approaches the "smart city" implies developing urban environment and social interactions favoring not only the fullest satisfaction of the developing needs of the population but also the most effective realization of human potential in activities aimed for the city sustainable development.

In our opinion, an Arctic city can be defined as "smart" when investments are aimed at increasing the long-term viability of the urban community, primarily through the codevelopment of citizens (human potential) and socio-technical structures with the support of relevant socio-humanitarian technologies. Continuous innovation development should be aimed at a long-term improvement of the viability of urban communities and the quality of life of people through harmonious synergetic socio-technological development of different city stakeholders and their ecological interaction with the environment.

Thus, the socio-techno-ecosystem of a "smart city" can be sustainably self-developing 
based on a spiral model with the basic cycle "human development - innovation - the quality of life". Quality of life is broadly understood as human development subjectively and objectively reflected in the growth of the level and quality of life, expanding opportunities for human realization and development. Human development is the main humanistic sense of developing a smart city, from the one hand, and, from the other hand, human potential is means of developing a smart city (creating and using knowledge, requiring new skills and qualifications to solve new problems and tasks of cities' sustainable development, social, innovative, and entrepreneurial activity, developing a more effective and flexible structure of communications and socio-economic interactions). The cycle "human development innovation - the quality of life" corresponds to the basic dialectical laws and humanistic values and implies constant development of the individual and collective worldviews.

\section{Conclusion}

Socio-cultural, humanistic, and activity approaches are prior valid methodological bases for the "smart city" concept considering that value of human life and development is in the main sense of sustainable urban development. The socio-cultural concept of a "smart" Arctic city implies co-development of human potential and urban space aimed at increasing the ability of urban communities to respond to the challenges and ensure long-term sustainable development. The socio-cultural model of "smart" Arctic cities implies rational basic vital infrastructure design but focuses on the developmental conditions. Arctic "smart cities" should develop as places for storing experience, transferring, and developing specific skills, intelligence, and competencies, as well as places of comfortable living for peoples who preserve arctic nature and develop the territory for current and future generations. The depletion of natural resources became the basis for the creation of Arctic cities, but this approach will lead to their stagnation and resettlement without the transition to a new model of a steadily developing Arctic city.

The research results actualize the need for the development of an eco-socio-cultural model of Arctic "smart cities", which assumes the possibility of a new socio-economic trend of the Arctic society: "smart people - smart cities - sustainable regional development".

\section{Acknowledgment}

The work is carried out in the frames of the project "Man in the Arctic: the study of the humanitarian aspects of the integrated socio-economic development of the Arctic spaces of the West Siberian region" supported by the Arctic research center and authorities of YNAO.

\section{References}

1. J. Schot, L. Kanger, Res. Policy 47, 1045-1059 (2018) doi:10.1016/J.RESPOL.2018.03.009

2. K. Gruszka, Environ. Innov. Soc. Transitions (2017) doi:10.1016/j.eist.2016.09.002

3. E.U. von Weizsäcker, A. Wijkman, Come on! Capitalism, short-termism, population and the destruction of the planet (Springer, 2017) ISBN 9781493974191.

4. V.V. Glushchenko, Introduction to Crisisology. Financial crisisology. Crisis management (IP Glushch, Moscow, 2008)

5. A.O. Vylegzhanina, Stud. Russ. Econ. Dev. 28, 180-190 (2017) doi: 10.1134/S1075700717020125

6. L. Zhang, J. Wu, H. Liu, J. Clean. Prod. 172, 2234-2245 
doi:10.1016/J.JCLEPRO.2017.11.188

7. G.F. Detter, A.V. Kozlov, E.A. Malyshev, Transbaikal State Univ. Bull. 6, 104-117 (2015)

8. Decree of the President of the Russian Federation of May 7, 2018 "On national goals and strategic objectives of the development of the Russian Federation for the period up to 2024 (2018)

9. A.V. Sedov, Guigoz. Sci. Rev. 2015, 56-59 (2015)

10. Decree of the President of the Russian Federation of 02.05.2014 No. 296 On the land territories of the Arctic zone of the Russian Federation (2014)

11. EMISS Share of urban population in total population as of January 1

12. United Nations World Urbanization Prospects: The 2018 Revision, https://population.un.org/wup/DataQuery/

13. V.V. Fauser, T.S. Lytkina, A.V. Smirnov, Arct. Ecol. Econ. 28 (2017)

14. A.V. Altukhov, A.A. Dorofeeva, Socio-cultural aspects of Smart Cities. Russ. West Dialogue Cult. 2019, 18-22 (2019)

15. N. Srnicek, Platform capitalism (Theory Redux) (2017) ISBN 9781509504862

16. A. Greenfield, Against the smart city (Do projects, 2013)

17. A.M. Townsend, Smart Cities: Big Data, Civic Hackers (W.W. Norton\&Company, 2014)

18. A. Sen, Commodities and capabilities (North-Holland, 1985) ISBN 9780444877307

19. O.B. Ganin, I.O. Ganin, Ars Adm. 2014, 124-135 (2014)

20. M.V. Mizrahi, Sociol. Pedagog. Psychol. 2013, 24 (2013)

21. J.L. Tukkel, S.N. Jashin, Innovations 3, 30-35 (2019)

22. M. Boykova, I. Ilina, M. Salazkin, Foresight STI Gov. 10, 65-75 (2016) doi:10.17323/1995-459X.2016.3.65.75

23. S. Dirks, M. Keeling, J. Dencik, How Smart is Your City? (Helping Cities Measure Progress, 2009)

24. Ministry of Construction of Russia Project of Digitalization of Municipal Economy "Smart City", https://minstroyrf.gov.ru/trades/gorodskaya-sreda/proekt-tsifrovizatsiigorodskogo-khozyaystva-umnyy-gorod/

25. V.B. Zotov, Munic. Acad. 2019, 3-11 (2019)

26. N.I. Klimkovich, Manag. Soc. Econ. Syst. 2019, 34-35 (2019)

27. A.V. Sedov, P.D. Chelyshkov, S.A. Rujitskaya, M.G. Solntseva, The European Concept of "Smart City" (Elsevier BV, 2017)

28. N.I. Klimkovich, P.I. Klimkovich, Smart city: development concept 2020 (2020)

29. A.G. Teslinov, Econ. Strateg. 2020, 100-107 (2020)

30. P. Sorokin, M.P. Richard, Social and cultural dynamics: A study of change in major systems of art, truth, ethics, law and social relationships (2017) ISBN 9781351490603

31. A. Mol', Sociodynamics of culture (LKI, Moscow, 2007)

32. E.V. Orlova, Manuscript 7, 149-152 (2007)

33. I.I. Svirida, Slav. Stud. 2003, 14-24 (2003)

34. R. Florida, Cities and the creative class (2004) ISBN 0203997670

35. A.V. Altukhov, A.A. Dorofeeva, Russ. West Dialogue Cult. 2019, 18-22 (2019) 